\title{
INFLUENCE OF PEPTIDE P34 ON GENE EXPRESSION OF LISTERIA MONOCYTOGENES AND LISTERIA SEELEGERI
}

\section{RODRIGO DE ALMEIDA VAUCHER ${ }^{* 1,2,3}$, JANICE LUEHRING GIONGO ${ }^{4}$, MAGTON ESTIVALES ${ }^{2}$, VÍRGINIA CIELO RECH $^{3}$, VIVIAN SHINOBU KISHIMOTO NISHIHIRA ${ }^{3}$, CRISTIANE LUCHESE ${ }^{1}$, ETHEL ANTUNES WILHELM ${ }^{1}$, MATHEUS DELLAMÉA BALDISSERA ${ }^{5}$, LEONARDO QUINTANA SOARES LOPES ${ }^{3}$, ROBERTO CHRIST VIANNA SANTOS $^{5}$, ADRIANO BRANDELLI ${ }^{6}$}

1Post Graduate Program in Biochemistry and Bioprospecting, Center of Chemistry, Pharmaceutical and Food Science, Federal University of Pelotas (UFPel), Pelotas, 96010-900, Rio Grande do Sul, Brazil, ${ }^{2}$ Laboratory of Microbiological Research, Health Sciences, Franciscan University Center (UNIFRA), Santa Maria, 97010-032, Rio Grande do Sul, Brazil, ${ }^{3}$ Laboratory of Nanotechnology, Post Graduate Program in Nanosciences, Franciscan University Center, Santa Maria, 97010-032, Rio Grande do Sul, Brazil, ${ }^{4}$ Laboratory of Pharmaceutical Technology, University of High Uruguay Regional Integrated (URI), Santiago, 97700-000, Rio Grande do Sul, Brazil, 5 Microbiology and Parasitology Department, Health Sciences Center, Federal University of Santa Maria (UFSM), Santa Maria, 97105-900, Rio Grande do Sul, Brazil, 6Laboratory of Biochemistry and Applied Microbiology, Institute of Science and Technology of Food, Federal University of Rio Grande do Sul Email: rodvaucher@hotmail.com

Received: 05 Feb 2016 Revised and Accepted: 08 Nov 2016

\section{ABSTRACT}

Objective: Investigate the influence of the antimicrobial peptides P34 and nisin on the expression of genes associated with components of the cell surface of Listeria monocytogenes and Listeria seeligeri.

Methods: Antimicrobial activity was determined by addition of peptide P34 and nisin (12.5 $\mu \mathrm{g} / \mathrm{ml})$ onto Brain Heart Infusion agar (BHI) plates previously inoculated with indicator strains (L. monocytogenes ATCC 7644 or L. seeligeri AC 82/4) after incubation for $24 \mathrm{~h}$ at $37^{\circ} \mathrm{C}$ or $240 \mathrm{~h}$ at $4{ }^{\circ} \mathrm{C}$. Ribonucleic acid (RNA) was directly extracted from bacterial colonies at the border of the inhibition zones, and the expression levels of genes Dalanine-D-alanyl carrier protein ligase (dltA), putative phospholipid lysinylation (Imo 1695) and EIIABMan of mannose-specific PTS ( $m p t A$ ) were determined using real-time PCR.

Results: A non-significant increase in the levels of transcription of genes $d$ ltA, Imo1695 and mptA was observed for L. monocytogenes treated with peptide P34 or nisin. Both peptides caused a similar decrease in dltA gene expression in L. seeligeri. The expression of gene Imo1695 significantly decreased (about 2000-fold) after treatment with the peptide P34 at $37^{\circ} \mathrm{C}$, while at $4{ }^{\circ} \mathrm{C}$ a reduction of 12 -fold and 5 -fold was detected for P34 and nisin, respectively. A significant decrease in $m p t A$ gene expression was observed by exposition to peptide P34 (31.872-fold) and nisin (16.047-fold) for $24 \mathrm{~h}$ at $37^{\circ} \mathrm{C}$.

Conclusion: The results suggest that both peptide P34 and nisin influence the expression of genes related with the cell-surface/cell-membrane structure of $L$. seeligeri and in lesser extent $L$. monocytogenes.

Keywords: Bacteriocin, L. monocytogenes, L. seeligeri, Gene expression

(C) 2017 The Authors. Published by Innovare Academic Sciences Pvt Ltd. This is an open access article under the CC BY license (http://creativecommons.org/licenses/by/4. 0/) DOI: http://dx.doi.org/10.22159/ijpps.2017v9i1.15391

\section{INTRODUCTION}

The genus Bacillus encompasses a number of industrially important species that have been recognised for years and are considered safe for biotechnological purposes. Bacillus subtilis, Bacillus thuringiensis, Bacillus stearothermophilus, Bacillus licheniformis, Bacillus megaterium and Bacillus cereus are examples of typical producers [1-12].

Bacteriocins and bacteriocin-like substance (BLS) are antimicrobial peptides produced by diverse bacteria and are often effective against closely related species $[4,13]$. Currently, BLS have gaining increased attention due to their potential use as natural preservatives in the food industry, due to activity against many pathogenic bacteria and the highest activity against Listeria species $[14,15]$. An example is a nisin, a non-toxic bacteriocin hydrolyzed by digestive enzymes that have been used for over $50 \mathrm{y}$ as a food preservative in different countries without the substantial development of bacterial resistance $[16,17]$. Until recently, it was believed that bacteria could not acquire resistance to antimicrobial peptides, so these substances would be strong candidates for new preservative in foods [18-20]. The development of resistance to antimicrobial peptides from previously sensitive strains has been viewed as difficult not impossible, but some studies have revealed that certain genes can provide increased resistance to antimicrobial peptides [21].

Studies on the structure, activity and gene expression of Listeria species indicate that the use of bacteriocins can induce the development of resistance in some target bacterial strains [22-24]. These studies have suggested that the interaction of class II bacteriocins is highly dependent on EIIMan and that the mechanism of resistance to class II bacteriocins can be observed in strains of $L$. monocytogenes, in which resistance seems to be associated to reduced expression of a mannose-specific phosphotransferase system (EIIABMan PTS, encoded by $m p t A$ ) [25]. The expression of genes like dltA and Imo 1695, which can potentially influence the cell-surface charge by D-alanyl-esterification of teichoic acid and lysinylation of membrane phospholipids, has been investigated as well. In addition, it has been described cross-resistance to class I and class II bacteriocins $[26,27]$, and the combined use of different bacteriocins can be successful to reduce the appearance of resistant strains.

A novel antimicrobial peptide was produced by a Bacillus sp. isolated from aquatic environments of Brazilian Amazon basin [28], with the potential to be used as food preservative. This peptide, named as P34, was purified and characterised as described elsewhere [29]. The peptide P34 was active against Gram-positive and Gramnegative bacteria, including pathogenic and spoilage microorganisms, with remarkable inhibitory activity on $L$. monocytogenes [30]. As the peptide P34 targets the cell envelope of L. monocytogenes, it is conceivable that P34 may also influence the expression of some genes after direct incubation with Listeria species. Thus, the aim of this study was to investigate the influence of antimicrobial peptide P34 on the gene expression of $L$. monocytogenes and L. seeligeri after direct plate inoculation. 


\section{MATERIALS AND METHODS}

\section{Bacterial strains and media}

L. monocytogenes ATCC 7644 and L. seeligeri AC 82/4 and Bacillus sp. strain P34, belonging to our own culture collection (UFRGS, Porto Alegre, Brazil), were grown in Brain Heart Infusion (BHI; Oxoid, Basingstoke, UK) broth or agar. Bacterial strains were maintained as stock cultures were frozen at $-21^{\circ} \mathrm{C}$ in BHI broth supplemented with $20 \%$ glycerol. For the production of the peptide, Bacillus sp. strain P34 was grown in BHI broth and detection of antimicrobial activity was performed in BHI agar plates.

\section{Peptide P34}

The peptide P34 was purified as described elsewhere [29]. Briefly, Bacillus sp. was cultivated in $500 \mathrm{ml}$ Erlenmeyer flasks containing $200 \mathrm{ml}$ of BHI broth for $24 \mathrm{~h}$ at $30^{\circ} \mathrm{C}$ in a rotary shaker at $180 \mathrm{rpm}$ (LAC-INA-800, Láctea). Cells were harvested by centrifugation at $10.000 \times g$ for $15 \mathrm{~min}$ at $12^{\circ} \mathrm{C}$, and the resulting supernatant was filtered through $0.22 \mu \mathrm{m}$ membranes (Millipore, Bedford, MA, USA). The peptide was purified from the supernatant by ammonium sulfate precipitation and sequential liquid chromatography on Sephadex G-100 and DEAE-Sepharose (Pharmacia Biotech, Uppsala, Sweden). The purification factor was 175 -fold and the concentration used was $12.5 \mathrm{\mu g} \mathrm{ml}^{-1}$. Nisin (Nisaplin ${ }^{\circledR}$; Danisco, Copenhagen, Denmark) was suspended in $0.02 \mathrm{~mol} \mathrm{l}^{-1} \mathrm{HCl}$ and then diluted in phosphate buffer saline (PBS; $35 \mathrm{mmol} \mathrm{l}^{-1}$ phosphate buffer, 150 mmol l-1 NaCl, pH 7.4) to obtain a solution of $12.5 \mu \mathrm{g} \mathrm{ml}^{-1}$. The concentrations of peptide P34 and nisin were determined by the Folin-phenol reagent method [31], using a calibration curve developed with bovine serum albumin as the protein standard.

\section{Detection of antimicrobial activity}

Antimicrobial activity was determined essentially as described elsewhere [32]. Briefly, aliquots of $20 \mu \mathrm{l}$ of purified peptide P34 and nisin were applied on cellulose disks $(6 \mathrm{~mm})$ on BHI agar plates previously inoculated with indicator strain suspension (L. monocytogenes ATCC 7644 or L. seeligeri AC 82/4), which corresponded to 0.5 McFarland turbidity standard solution. The plates were incubated for $24 \mathrm{~h}$ at $37^{\circ} \mathrm{C}$ for bacteriological incubator (MA 032/3, Marconi, Piracicaba, SP, Brazil) or $240 \mathrm{~h}$ at $4^{\circ} \mathrm{C}$. After incubation, inhibition zones around the disks were measured. PBS was used as a negative control. The experiments were performed in triplicate $(n=3)$ and the expressed values as mean $\pm S D$ of three independent experiments.

\section{Relative levels transcript of genes for real-time PCR quantification}

Bacterial cells of L. monocytogenes ATCC 7644 and L. seeligeri AC 82/4 were removed directly at the border around the inhibition zones after 24 $\mathrm{h}$ and $240 \mathrm{~h}$ of incubation of negative control, peptide P34, and nisin, respectively. The cell concentration was adjusted spectrophotometrically by 0 . D. $600 \mathrm{~nm}$ for a final concentration of $2 \mathrm{x}$ $10^{4} \mathrm{cells} / \mathrm{ml}$. The TRIZOL ${ }^{\circledR}$ (Invitrogen, Carlsbad, CA) reagent was utilised for total RNA extraction, according to the manufacturer's instructions.
Then, the extracted RNA was treated with RNase-free DNase (Invitrogen, Carlsbad, CA), its quality was assessed by running samples on a $1 \%$ formaldehyde-agarose gel, and quantified spectrophotometrically. The primers used in this study were previously described by $[12,47]$ were named: dltA F 5'CACAAGATCAGCTAATGGACGC3', dltA R 5'CTGGAACTTCTCCGAAATGTTT3', Imo1695 F 5'GGGATTGACTA-TCCGTCGCTA3', Imo1695 R 5' TTCCGGGCTTTGAGAAGTTAA3', mptA F 5'CAGGACTTAATTTGCCAATGTTG3', mptA R 5'CGCGAACACCTTCTT-GAGCT3', $r p o D$ F 5'ACTGAAAAAGTTCGGGAAATCCT3' and rpoD R 5' TCGCCTAGATGTGAATCGTCTTC3'. The real-time PCR amplification reaction was carried using SYBR ${ }^{\circledR}$ Green One-Step qRT-PCR with Rox (Invitrogen, Carlsbad,CA), according to the manufacturer's instructions. cDNA was synthesised from $0.5 \mu \mathrm{g}$ of total RNA of L. monocytogenes ATCC 7644 or L. seeligeri AC $82 / 4$, using the forward and reverse primers $(100 \mu \mathrm{M})$ specific for each target gene. Amplification conditions were: $48^{\circ} \mathrm{C}$ for 30 min, $50{ }^{\circ} \mathrm{C}$ for $2 \mathrm{~min}$ and $95^{\circ} \mathrm{C}$ for $10 \mathrm{~min}$, followed by 40 cycles at $95^{\circ} \mathrm{C}$ for $15 \mathrm{~s}$ and $60^{\circ} \mathrm{C}$ for $1 \mathrm{~min}$. All PCR reactions were run on the 7500 Real-Time PCR System (Applied Biosystems ${ }^{\circledR}$, USA). The assays were accomplished in duplicated $(\mathrm{n}=2)$ for each gene, and include cDNA of the samples and control without template on three independent experiments.

The data were analysed using Sequence Detection System (SDS) software version 1.6.3. Results were obtained as $\mathrm{C}_{\mathrm{T}}$ (threshold cycle) values. The mean $\left(\mathrm{C}_{\mathrm{T}}\right)$ value was calculated for each triplicate reaction in two independent experiments. The $\left(\Delta C_{T}\right)$ values were calculated and normalised by subtracting the mean $\left(\mathrm{C}_{\mathrm{T}}\right)$ value of $L$. monocytogenes ATCC 7644; L. see ligers AC 82/4 and control by mean $\left(\mathrm{C}_{\mathrm{T}}\right)$ values endogenous control (the rpoD gene encoding the $\sigma 70$ subunit of the RNA polymerase) to give the $\left(\Delta \Delta \mathrm{C}_{\mathrm{T}}\right)$ value. The $\left(\Delta \Delta \mathrm{C}_{\mathrm{T}}\right)$ value was calculated subtracting $\left(\Delta \mathrm{C}_{\mathrm{T}}\right)$ value of $L$. monocytogenes ATCC 7644 or $L$. seeligeri AC $82 / 4$ by $\left(\Delta \mathrm{C}_{\mathrm{T}}\right.$ ) value control. The relative expression of each gene can be quantitatively calculated as $\left(2-\Delta \Delta \mathrm{C}_{\mathrm{T}}\right)$, as described by [12].

\section{Statistical analysis}

Treatment comparisons were performed using Tukey's $t$-test and the values were considered significantly different each other at $P<0.05$.

\section{RESULTS AND DISCUSSION}

Increased resistance of microbial strains has been associated with the use of antimicrobials applied to the food preservation, including strains of $L$. monocytogenes [34]. Some strains isolated from foods have become resistant to conventional bacteriocins such as nisin, pediocin PA- 1 and bavaricin $[35,36]$. Under the experimental conditions of this work, $L$. monocytogenes was more sensitive than $L$. seeligeri when exposed to nisin and peptide P34. The inhibition zones of peptide P34 and nisin against $L$. monocytogenes and $L$. seeligeri after the incubation time of $24 \mathrm{~h}$ at $37^{\circ} \mathrm{C}$ and $240 \mathrm{~h}$ at $4{ }^{\circ} \mathrm{C}$ are shown in table 1 . This study showed that nisin produced larger inhibitory halos than the peptide P34 against the strain of $L$. seeligeri, although both substances were inhibitory to the Listeria strains tested. Our results for the antimicrobial activity were similar to a previously published study [37].

Table 1: Antimicrobial activity of purified peptide P34, nisin, and control

\begin{tabular}{lll}
\hline Indicator strain & Conditions & Inhibition zone (mm) $^{*}$ \\
\hline & $24 \mathrm{~h}$ incubation at $37^{\circ} \mathrm{C}$ & 0 \\
Listeria monocytogenes ATCC7644 & Control & $9.0 \pm 0.2$ \\
& $\mathrm{P} 34 \mathrm{Nisin}$ & $10.0 \pm 0.3$ \\
& $240 \mathrm{~h}$ incubation at $4{ }^{\circ} \mathrm{C}$ & 0 \\
& Control & $10.0 \pm 0.1$ \\
& P34 & $12.0 \pm 0.2$ \\
Nisteria seeligeri AC82/4 & $24 \mathrm{~h}$ incubation at $37^{\circ} \mathrm{C}$ & 0 \\
& Control & $10.0 \pm 0.3$ \\
& P34 & $12.0 \pm 0.3$ \\
& Nisin & 0 \\
& Control & $9.0 \pm 0.2$ \\
& P34 & $10.0 \pm 0.1$ \\
\hline
\end{tabular}

*Diameter of the inhibition zone in $\mathrm{mm}$ around the disk. The experiments were performed in triplicate $(\mathrm{n}=3)$ and the expressed values as mean \pm SD of three independent experiments. 
Based on the inhibition of L. monocytogenes and L. seeligeri by peptide P34 and nisin, the expression of three different genes of Listeria genus, namely $d t t A$, imo1695, and $m p t A$, were evaluated by real-time PCR. It has been reported that changes in cell surface may occur after the interaction of class IIa bacteriocins with specific receptors of bacterial cell wall, which could be associated with an increase in the transcription level of certain genes in some strains of L. monocytogenes [38]. Another gene investigated was the mptA, which has been reported as a mannose permease, named EII ${ }^{\mathrm{Man}}$, belonging to the phosphotransferase system (PTS). The PTS is responsible for the transport and concomitant phosphorylation of sugars inside both Gram-negative and Gram-positive bacteria [39].

The values of $\Delta \mathrm{C}_{\mathrm{T}}$ and $\Delta \Delta \mathrm{C}_{\mathrm{T}}$ to calculate the relative expression levels $\left(2-\Delta \Delta C_{T}\right)$ of strains of $L$. monocytogenes and L. seelegeri, are shown in table 2 .

Table 2: Calculated and analysed relative transcript levels of genes by real-time PCR quantification after incubation of $L$. monocytogenes ATCC 7644 (A) and L. seeligeri AC 82/4 (B) with antimicrobial peptides

A

\begin{tabular}{|c|c|c|c|c|c|}
\hline Gene & Time and temperature of incubation & Group & $\Delta \mathrm{C}_{\mathrm{T}}$ & $\Delta \Delta \mathrm{C}_{\mathrm{T}} *$ & $2-\Delta \Delta \mathrm{C}_{\mathrm{T}}$ \\
\hline \multirow[t]{6}{*}{ dlta } & $24 \mathrm{~h}$ at $37^{\circ} \mathrm{C}$ & Control & $0.12 \pm 0.045$ & 0 & 1.0 \\
\hline & & P34 & $1.27 \pm 0.042$ & $1.16 \pm 0.003$ & 0.44 \\
\hline & & Nisin & $1.99 \pm 0.142$ & $1.87 \pm 0.097$ & 0.27 \\
\hline & $240 \mathrm{~h}$ at $4^{\circ} \mathrm{C}$ & Control & $0.54 \pm 0.065$ & 0 & 1.0 \\
\hline & & P34 & $0.80 \pm 0.082$ & $0.25 \pm 0.017$ & 0.84 \\
\hline & & Nisin & $1.84 \pm 0.097$ & $1.29 \pm 0.032$ & 0.40 \\
\hline \multirow[t]{6}{*}{ Imo 1695} & $24 \mathrm{~h}$ at $37^{\circ} \mathrm{C}$ & Control & $1.18 \pm 0.052$ & 0 & 1.0 \\
\hline & & P34 & $3.39 \pm 0.187$ & $2.21 \pm 0.135$ & 0.21 \\
\hline & & Nisin & $4.05 \pm 0.121$ & $2.87 \pm 0.069$ & 0.13 \\
\hline & $240 \mathrm{~h}$ at $4^{\circ} \mathrm{C}$ & Control & $1.28 \pm 0.057$ & 0 & 1.0 \\
\hline & & P34 & $1.52 \pm 0.071$ & $0.25 \pm 0.014$ & 0.84 \\
\hline & & Nisin & $2.92 \pm 0.139$ & $1.65 \pm 0.082$ & 0.31 \\
\hline \multirow[t]{6}{*}{$m p t A$} & $24 \mathrm{~h}$ at $37^{\circ} \mathrm{C}$ & Control & $-0.23 \pm 0.076$ & 0 & 1.0 \\
\hline & & P34 & $0.26 \pm 0.057$ & $0.49 \pm 0.019$ & 0.71 \\
\hline & & Nisin & $1.69 \pm 0.154$ & $1.92 \pm 0.078$ & 0.26 \\
\hline & $240 \mathrm{~h}$ at $4^{\circ} \mathrm{C}$ & Control & $-0.45 \pm 0.057$ & 0 & 1.0 \\
\hline & & P34 & $0.27 \pm 0.086$ & $0.72 \pm 0.029$ & 0.60 \\
\hline & & Nisin & $1.65 \pm 0.128$ & $2.10 \pm 0.071$ & 0.23 \\
\hline \multicolumn{6}{|c|}{ B } \\
\hline Gene & Time and temperature of incubation & Group & $\Delta \mathbf{C}_{\mathrm{T}}$ & $\Delta \Delta \mathrm{C}_{\mathrm{T}} *$ & $2-\Delta \Delta \mathrm{C}_{\mathrm{T}}$ \\
\hline \multirow[t]{6}{*}{ dltA } & $24 \mathrm{~h}$ at $37^{\circ} \mathrm{C}$ & Control & $4.90 \pm 0.302$ & 0 & 1.0 \\
\hline & & P34 & $1.88 \pm 0.183$ & $-3.02 \pm 0.119$ & $8.11^{*}$ \\
\hline & & Nisin & $1.83 \pm 0.190$ & $-3.07 \pm 0.112$ & $8.39^{*}$ \\
\hline & $240 \mathrm{~h}$ at $4^{\circ} \mathrm{C}$ & Control & $4.99 \pm 0.197$ & 0 & 1.0 \\
\hline & & P34 & $1.72 \pm 0.111$ & $-3.27 \pm 0.086$ & $9.64^{*}$ \\
\hline & & Nisin & $1.19 \pm 0.148$ & $-3.80 \pm 0.049$ & $13.92^{*}$ \\
\hline \multirow[t]{6}{*}{ Imo 1695} & $24 \mathrm{~h}$ at $37^{\circ} \mathrm{C}$ & Control & $3.62 \pm 0.342$ & 0 & 1.0 \\
\hline & & P34 & $-7.57 \pm 0.201$ & $-11.19 \pm 0.141$ & $2336.2^{*}$ \\
\hline & & Nisin & $2.61 \pm 0.175$ & $-1.00 \pm 0.119$ & 2.0 \\
\hline & $240 \mathrm{~h}$ at $4^{\circ} \mathrm{C}$ & Control & $5.52 \pm 0.223$ & 0 & 1.0 \\
\hline & & P34 & $1.83 \pm 0.118$ & $-3.69 \pm 0.105$ & $12.9^{*}$ \\
\hline & & Nisin & $3,07 \pm 0.165$ & $-2.44 \pm 0.058$ & $5.42^{*}$ \\
\hline \multirow[t]{6}{*}{$m p t A$} & $24 \mathrm{~h}$ at $37^{\circ} \mathrm{C}$ & Control & $-7.38 \pm 0.277$ & 0 & 1.0 \\
\hline & & P34 & $-7.58 \pm 0.154$ & $-14.96 \pm 0.123$ & $31872.0^{*}$ \\
\hline & & Nisin & $-6.59 \pm 0.132$ & $-13.97 \pm 0.145$ & $16047.0^{*}$ \\
\hline & $240 \mathrm{~h}$ at $4{ }^{\circ} \mathrm{C}$ & Control & $-2.70 \pm 0.228$ & 0 & 1.0 \\
\hline & & P34 & $0.07 \pm 0.147$ & $2.78 \pm 0.081$ & 0.14 \\
\hline & & Nisin & $-0.17 \pm 0.165$ & $2.52 \pm 0.063$ & 0.17 \\
\hline
\end{tabular}

${ }^{*}$ Relative gene expression considered significant for values $\leq-3$ or $\geq 3$. The experiments were performed in duplicated $(\mathrm{n}=2)$ for each gene on three independent experiments. dltA (D-Alanine-D-alanyl carrier protein ligase), Imo 1695 (Putative phospholipid lysinylation) and mptA (EIIABMan of mannose-specific PTS).

A significant change in the gene expression level was considered when a three-fold decreased or increased expression was obtained in comparison to control. Our results showed a non-significant increase in the transcription levels of genes dItA, Imo1695 and mptA after incubation of L. monocytogenes with peptide P34 and nisin for $24 \mathrm{~h}$ at $37^{\circ} \mathrm{C}$ or $240 \mathrm{~h}$ at $4{ }^{\circ} \mathrm{C}$

For the expression levels of dltA and Imo1965, our results are consistent with those proposed by [40], who also found no significant changes in expression of these genes in wild-type strains of $L$. monocytogenes. The L. monocytogenes used in this study is a collection strain (ATCC) and the decrease of $m p t A$ gene expression has been reported only for resistant or mutant strains of $L$ monocytogenes $[38,40,41]$. Therefore the result of a non-significant increase in $m p t A$ gene expression in L. monocytogenes ATCC 7644 is consistent with the literature.

In the strain of L. seeligeri, a significant decrease of dltA gene expression was observed, with similar values to the peptide P34 and nisin after incubation for $24 \mathrm{~h}$ at $37{ }^{\circ} \mathrm{C}$. The expression of this gene was highly suppressed after incubation for $240 \mathrm{~h}$ at $4{ }^{\circ} \mathrm{C}$, and the treatment with nisin resulted in lower $d l t A$ expression as compared with the peptide P34. The gene Imo1695 showed a significant decrease in its expression (2336-fold) when L. seeligeri was treated with the peptide P34 for $24 \mathrm{~h}$ at $37{ }^{\circ} \mathrm{C}$. A significant decrease of Imo1695 gene expression was observed after incubation with peptide P34 and nisin for $24 \mathrm{~h}$ at $37{ }^{\circ} \mathrm{C}$. Under this condition, the 
gene Imo1695 was two times less expressed by nisin treatment as compared with the peptide P34.

A significant decrease in $m p t A$ gene expression was also observed for L. seeligeri after incubation with peptide P34 and nisin for $24 \mathrm{~h}$ at 37 ${ }^{\circ} \mathrm{C}$. This gene was 31.872 -fold less expressed after treatment with the peptide P34 as compared with the control. In addition, the expression of this gene was significantly lower after treatment with nisin. Interestingly, the inoculation of the plate with the peptide P34 and nisin and further incubated for $240 \mathrm{~h}$ at $4{ }^{\circ} \mathrm{C}$ showed a non-significant increase of gene expression. Listeria thrives at refrigeration temperatures and therefore is feasible that the exposition to low temperature would influence the expression of genes related with energetic metabolisms, such as $m p t A$. Recently, the influence of P34 on specific gene expression of $L$. monocytogenes after the inoculation in Minas Frescal cheese was investigated. A significant increase in the expression of the genes dltA, Imo 1695 and $m p t A$ was observed after $96 \mathrm{~h}$ in the presence of peptide $\mathrm{P} 34$ at $5^{\circ} \mathrm{C}$ [12].

Previous studies have shown that a 1000-fold increased resistance to class IIa bacteriocins in L. monocytogenes and Enterococcus faecalis resulted from the loss of $m p t A$ expression [38, 42, 43]. The cell wall of $L$. monocytogenes is composed by a thick peptidoglycan layer containing two types of anionic polymers: teichoic acids (TA), which are covalently linked to the peptidoglycan, and lipoteichoic acids (LTAs), which are poly phosphoglycerols substituted with a Dalanyl ester or a glycosyl residue and anchored in the membrane by their glycolipid moiety [44]. Some authors suggest that bacteriocininduced lysis could be due to the release of autolytic enzymes that are usually electrostatically bound to anionic polymers (TA and LTAs) of the cell wall, which are displaced by cationic bacteriocins from their binding sites [45-47].

\section{CONCLUSION}

In this study, we observed a non-significant influence of peptide P34 and nisin on the expression of L. monocytogenes genes after the plate activity assay. However, in $L$. seeligeri the peptide P34 and nisin significantly influenced the expression of genes (dltA, Imo1685, and $m p t A$ ) after incubation for $24 \mathrm{~h}$ at $37{ }^{\circ} \mathrm{C}$. After an incubation period of $240 \mathrm{~h}$ at $4{ }^{\circ} \mathrm{C}$, it was observed the more significant changes in gene expression (dltA and Imo1685) in L. seeligeri, but no significant change was observed for $m p t A$ gene. These results indicate the influence of nisin and peptide P34 on the expression of structural cell-surface/cell-membrane-associated genes.

\section{ACKNOWLEDGEMENT}

Authors thank Sérgio Salla Chagas from the Laboratory of Molecular Biology of LANAGRO/RS, Ministry of the Agriculture (Brazil), to facilitate the equipment for real-time PCR studies. This work received financial support of $\mathrm{CNPq}$, Brazil.

\section{CONFLICT OF INTERESTS}

\section{Declared none}

\section{REFERENCES}

1. Shafia F. Thermocins of Bacillus stearothermophilus. J Bacteriol 1966;92:524-5.

2. Bradley DE. Ultrastructure of bacteriophage and bacteriocins. Bacteriol Rev 1967;31:230-314.

3. Tagg JR, Dajani AS, Wannamaker LW. Bacteriocins of grampositive bacteria. Bacteriol Rev 1976;40:722-56.

4. Favret ME, Yousten AA. Thuricin: the bacteriocin produced by Bacillus thuringiensis. J Invertebr Pathol 1989;53:206-16.

5. Naclerio G, Ricca E, Sacco M, De Felice M. Antimicrobial activity of a newly identified bacteriocin of Bacillus cereus. Appl Environ Microbiol 1993;59:4313-16.

6. Paik HD, Bae SS, Park SH, Pan JG. Identification and partial characterization of tochicin, a bacteriocin produced by Bacillus thuringiensis subsp tochigiensis. J Ind Microbiol Biotechnol 1997;19:294-8.

7. Hyronimus B, Le Marrec C, Urdaci MC. Coagulin, a bacteriocinlike inhibitory substance produced by Bacillus coagulans I4. J Appl Microbiol 1998;85:42-50.
8. Oscáriz JC, Lasa I, Pisabarro AG. Detection and characterization of cerein 7, a new bacteriocin produced by Bacillus cereus with a broad spectrum of activity. FEMS Microbiol Lett 1999;178:337-41.

9. Cherif A, Ouzari H, Daffonchio D, Cherif H, Ben Slama K, Hassen A, et al. Thuricin 7:a novel bacteriocin produced by Bacillus thuringiensis BMG1.7, a new strain isolated from soil. Lett Appl Microbiol 2001;32:243-7.

10. Bizani D, Brandelli A. Characterization of a bacteriocin produced by a newly isolated Bacillus sp. strain $8 \mathrm{~A}$. J Appl Microbiol 2002;93:512-9.

11. Stein T. Bacillus subtilis antibiotics: structures, syntheses and specific functions. Mol Microbiol 2005;56:845-57.

12. Vaucher RA, Giongo JL, Rech VC, Santos, RCV, Lopes LQS, et al. Antimicrobial peptide P34 influences gene expression of Listeria monocytogenes growing in soft cheese. Int J Pharm Pharm Sci 2016;8:235-9.

13. Kaur G, Singh T, Malik R. Antibacterial efficacy of nisin, pediocin 34 and enterocin FH99 against Listeria monocytogenes and cross-resistance of its bacteriocin resistant variants to common food preservatives. Braz J Microbiol 2013;44:63-71.

14. Eijsink VGH, Skeie M, Middelhoven PH, Brurberg MB, Nes IF. Comparative studies of class IIa bacteriocins of lactic acid bacteria. Appl Environ Microbiol 1998;64:3275-81.

15. Twomey D, Ross RP, Ryan M, Meaney B, Hill C. Lantibiotics produced by lactic acid bacteria: structure, function and applications. Antonie Van Leeuwenhoek 2002;82:165-85.

16. De Martinis ECP, Públio MRP, Santarosa PR, Freitas FZ. The antilisterial activity of lactic acid bacteria isolated from vacuum-packaged Brazilian meat and meat products. Braz J Microbiol 2001;32:32-7.

17. Deegan LH, Cotter PD, Hill C, Ross P. Bacteriocins: biological tools for biopreservation and shelf-life extension. Int Dairy J 2006;16:1058-71.

18. Scott MG, Hancock RE. Cationic antimicrobial peptides and their multifunctional role in the immune system. Crit Rev Immunol 2000;20:407-31.

19. Hancock REW, Rozek A. Role of membranes in the activities of antimicrobial cationic peptides. FEMS Microbiol Lett 2002;206:143-9.

20. Bradshaw J. Cationic antimicrobial peptides: issues for potential clinical use. BioDrugs 2003;17:233-40.

21. Hancock R, Chapple D. Peptide antibiotics. Antimicrobial Agents Chemother 1999;43:1317-23.

22. Crandall AD, Montville TJ. Nisin resistance in Listeria monocytogenes ATCC 700302 is a complex phenotype. Appl Environ Microbiol 1998;64:231-7.

23. Peschel A, Otto M, Jack RW, Kalbacher H, Jung G, Götz F. Inactivation of the dlt operon in Staphylococcus aureus confers sensitivity to defensins, protegrins, and other antimicrobial peptides. J Biol Chem 1999;274:8405-10.

24. Rodríguez-Lázaro $\mathrm{D}$, Hernández $\mathrm{M}$, Scortti $\mathrm{M}$, Esteve $\mathrm{T}$, Vázquez-Boland JA, Pla M. Quantitative detection of Listeria monocytogenes and Listeria innocua by real-time PCR: assessment of hly, iap, and lin02483 targets and ampli fluor technology. Appl Environ Microbiol 2004;70:1366-77.

25. Cotter PD, Hill C, Ross RP. Bacteriocins: developing innate immunity for food. Nat Rev Microbiol 2005;3:777-88.

26. Bouttefroy $A$, Millière JB. Nisin-curvaticin 13 combinations for avoiding the regrowth of bacteriocin resistant cells of Listeria monocytogenes ATCC 15313. Int J Food Microbiol 2000;62:65-75.

27. Gravesen A, Kallipolitis B, Holmstrøm K, Høiby PE, Ramnath M, Knøchel S. pbp2229-mediated nisin resistance mechanism in Listeria monocytogenes confers cross-protection to class IIa bacteriocins and affects virulence gene expression. Appl Environ Microbiol 2004;70:1669-79.

28. Motta AS, Cannavan FS, Tsai SM, Brandelli A. Characterization of a broad range antibacterial substance from a new Bacillus species isolated from Amazon basin. Arch Microbiol 2007;188:367-75.

29. Motta AS, Lorenzini DM. Brandelli a purification and partial characterization of an antimicrobial peptide produced by a novel Bacillus sp. isolated from the Amazon Basin. Curr Microbiol 2007;54:282-6. 
30. Motta A, Flores F, Souto A, Brandelli A. Antibacterial activity of a bacteriocin-like substance produced by Bacillus sp. P34 that targets the bacterial cell envelope. Antonie Van Leeuwenhoek 2008;93:275-84.

31. Lowry $\mathrm{OH}$, Rosebrough NJ, Farr AL, Randall RJ. Protein measurement with the Folin phenol reagent. J Biol Chem 1951;193:265-75.

32. Motta AS, Brandelli A. Characterization of an antibacterial peptide produced by Brevibacterium linens. J Appl Microbiol 2002;92:63-70.

33. Iancu C, Grainger A, Field D, Cotter P, Hill C, Ross R. Comparison of the potency of the lipid II targeting antimicrobials nisin, lacticin 3147 and vancomycin against Gram-positive bacteria. Probiotics Antimicrob Proteins 2012;4:108-15.

34. Riley MA, Wertz JE. Bacteriocins: evolution, ecology, and application. Annu Rev Microbiol 2002;56:117-37.

35. Rasch M, S Knøchel S. Variations in tolerance of Listeria monocytogenes to nisin, pediocin PA-1 and bavaricin A. Lett Appl Microbiol 1998;27:275-8.

36. Schaik, W van, Gahan CG, Hill C. Acid-adapted Listeria monocytogenes displays enhanced tolerance against the lantibiotics nisin and lacticin 3147. J Food Protect 1999;62:536-9.

37. Sant'Anna V, Quadros DAF, Motta AS, Brandelli A. Antibacterial activity of bacteriocin-like substance P34 on Listeria monocytogenes in chicken sausage. Braz J Microbiol 2013;44:1163-7.

38. Gravesen A, Ramnath M, Rechinger KB, Andersen N, Jänsch L, Héchard Y, et al. High-level resistance to class IIa bacteriocins is associated with one general mechanism in Listeria monocytogenes. Microbiology 2002;148:2361-9.

39. Postma PW, Lengeler JW, Jacobson GR. Phosphoenolpyruvate: carbohydrate phosphotransferase systems of bacteria. Microbiol Rev 1993;57:543-94.

40. Vadyvaloo V, Arous S, Gravesen A, Hechard Y, ChauhanHaubrock R, Hastings JW, et al. Cell-surface alterations in class IIa bacteriocin-resistant Listeria monocytogenes strains. Microbiology 2004;150:3025-33.
41. Gravesen A, Warthoe P, Knochel S, Thirstrup K. Restriction fragment differential display of pediocin-resistant Listeria monocytogenes 412 mutants shows consistent overexpression of a putative beta-glucoside-specific PTS system. Microbiology 2000;146:1381-9.

42. Ramnath M, Beukes M, Tamura K, Hastings J. Absence of a putative in a leucocin A resistant strain of Listeria monocytogenes, as shown by two-dimensional sodium dodecyl sulfate polyacrylamide gel electrophoresis. Appl Environ Microbiol 2000;66:3098-101.

43. Dalet K, Cenatiempo Y, Cossart P, Héchard Y. A sigmadependent PTS permease of the mannose family is responsible for sensitivity of Listeria monocytogenes to mesentericin Y105. Microbiology 2001;147:3263-9.

44. Weidenmaier C, Peschel A. Teichoic acids and related cell-wall glycopolymers in Gram-positive physiology and host interaction. Nat Rev Microbiol 2008;6:276-87.

45. Jack R, Tagg J, Ray B. Bacteriocins of gram-positive bacteria Microbiol Rev 1995;59:171-200.

46. Maisnier-Patin S, Richard J. Cell wall changes in nisin-resistant variants of Listeria innocua grow in the presence of high nisin concentrations. Microbiol Rev 1996;140:29-35.

47. Vadyvaloo V, Hastings J, Van der Merwe M, Rautenbach MJ. Membranes of class IIa bacteriocin-resistant L. monocytogenes cells contain increased levels of desaturated and short-acylchain phosphatidylglycerols. Appl Environ Microbiol 2002 . 68:5223-30.

\section{How to cite this article}

- $\quad$ Rodrigo De Almeida Vaucher, Janice Luehring Giongo, Magton Estivales, Vírginia Cielo Rech, Vivian Shinobu Kishimoto Nishihira, Cristiane Luchese, Ethel Antunes Wilhelm, Matheus Dellaméa Baldissera, Leonardo Quintana Soares Lopes, Roberto Christ Vianna Santos, Adriano Brandelli. Influence of peptide P34 on gene expression of Listeria monocytogenes and Listeria seelegeri. Int J Pharm Pharm Sci 2017;9(1):116-120. 